\title{
Gender Sensitivity in Textbooks in Secondary Education in Bhutan
}

\author{
Tshewang Dorji \\ Ohttps://orcid.org/0000-0002-9022-2314 \\ Dechencholing Higher Secondary School, Thimphu Thromde, Bhutan Ministry of Education \\ *e-mail: tshewangtshewang@gmail.com
}

\begin{tabular}{l}
\hline \multicolumn{1}{c}{ Article Information } \\
\hline Received: March 07, 2021 \\
Revised: March 29, 2021 \\
Accepted: April 05, 2021 \\
Online: August 11, 2021
\end{tabular}

\section{Keywords}

Secondary education, gender sensitivity, stereotypes, curriculum, textbooks

\begin{abstract}
This study was carried out to understand gender stereotypes in the curriculum framework and textbooks, which form the main curricular materials in schools in Bhutan. The researchers reviewed the curriculum framework for Accountancy, Economics, Mathematics, Science, Geography, History, and English. Except for the science curriculum framework, which states that science curriculum should be gender-sensitive in terms of materials used, language used, and ensuring the equal participation of boys and girls in activities, other frameworks were all silent on gender. Textbook reviews were carried out by teachers (22 female and 54 male) teaching classes IX to XII in clustered workshops using the Blumberg model of textbook analysis, which was employed to analyze gender biases in Vietnamese primary school textbooks. The findings revealed a presence of imbalance of gender among the authors, reviewers, editors, and designers, as well as gender biases, gender stereotyping in the content, illustrations, and student activity. It calls for curriculum developers and textbook authors to integrate gender in the curriculum framework, guiding the development of gender-sensitive textbooks.
\end{abstract}

\section{INTRODUCTION}

Goal 3 of the Millennium Development Goals adopted in 2000 is to promote gender equality and empower women with target 4 to eliminate gender disparity in primary and secondary education, preferably by 2005 and in all levels of education no later than 2015 (UNDP, 2003). Gender equality and women's empowerment are fundamental dimensions of human development and a necessary foundation for a prosperous, peaceful, and sustained world (UNICEF, 2017). Investing in girls' or women's education has multi-dimensional benefits (UNDP, 2016), such as eradicating poverty and enhancing economic and social development (World Bank, 2012). The failure of anti-poverty programs is due to women's issues at all stages of development (UNESCO, 2004).

For decades, Bhutan has maintained education as one of its top priorities. Education is provided free from Pre-Primary to class X. For instance, students are exempted from tuition and are provided with the textbook, sports items, learning materials, stationery and boarding facilities, and food based on need (MoE, 2019). Similar to many countries that have taken concrete measures to address gender inequities (UNESCO, 2004), Bhutan came up with various legal frameworks to protect and promote the rights of children and women, such as the Child Care and Protection Act of Bhutan 2011, National Youth Policy 2011, Child Adoption Act 2012, Domestic Violence Prevention Act 2013, and Gender Responsive Planning and Budgeting (GNHC, 2019). Subsequently, Bhutan has made significant progress in 
narrowing gender gaps in health, education, the labor force, and decision-making (GNHC, 2019). In 2017, female literacy improved to 59 percent from 55 percent in 2012 ( NSB, 2012). In 2016, the enrolment rate of women in higher education was 46 percent, an increase from 35 percent in 2005 with a gender parity of 0.85 . Similarly, in 2017, the composition of women in civil service was 35.43 , an increase from 32.4 percent in 2012 (GNHC, 2019).

However, the Bhutan Education Blue Print 2014-2024: Rethinking Education (MoE, 2014) states that fewer girls and women attend secondary school and higher education. The female enrolment in higher education continues to be lower, with 85 girls for every 100 boys. Similarly, the enrolment of girls in technical education and STEM subjects is low compared to boys (GNHC, 2019). Consequently, factors that drive gender inequality in secondary schooling are likely to impact gender inequality in higher education (Dorji, 2017). The Bhutan Education Blue Print 2014-2024 (MoE, 2014) recommends the education sector to develop gender-sensitive policies and provide enabling facilities and conditions, such as enough toilets, water supply, health rooms, and better security to enhance quality teachinglearning among girls and women in secondary education.

The textbooks are the most visible resources used by teachers and students in Bhutan. The conception, gender belief, and stereotypes are depicted in the textbooks. The role of men and women is not depicted truly and focuses more on men's achievement. Through textbooks, individual and societal behavior are determined (Saleem \& Zubair, 2013). The PISA-D Report (BCSEA, 2019) recommends that schools emphasize improving teachers' instructional and classroom management practices and break the gender stereotypes on all school subjects. The curriculum in many countries is implemented through textbooks and learning materials. According to Pigozzi (2000), there are five components: curriculum and materials, contents, materials, and methods to promote quality education and realize the full potential of learners, including boys and girls. Educational methods and contents must be rendered gender-sensitive. The teacher must be sensitized to the needs and situations of learners of both boys and girls (UNESCO, 2004). According to Saleem \& Zubair (2013, p.58).

Education plays a critical role in teaching young people about their rights, and textbooks are the most important part of this process. Gender discrimination does not end in school textbooks; however, because of children's in-school education and because of their lack of development in analytical thinking thus, school textbooks can be powerful tools for imprinting social and cultural values in their minds.

In many cases, the content analysis of textbooks showed men as the dominant figure. Pronoun 'he' is used now and then. Traditional gender stereotypes influence students' perception of their abilities and socialization between boys and girls (Buchmann, DiPrete \& MCDaniel, 2008). Stereotypes limit access to education and undermine the quality of educational methods and material content (UNESCO, $\underline{2004})$.

Textbooks and learning materials play an important role in shaping attitudes, values, and social skills to achieve gender equality. Gender inequality hampers the growth and development of nations. It widens the earnings gap between males and females, impedes women's participation in society, and restrain women's voices (World Bank, 2011). Textbooks are often used as the only teaching-learning resource that teachers and students use in the school (MOET, 2010). Often, textbooks and teachinglearning materials are not scrutinized for gender stereotypes and biases. According to the Forum for African Women Educationalists ( men as superior and women as submissive and helper. Men are doctors, engineers, pilots, and traders, while women are cooks, nurses, and secretaries. The analysis of the chemistry textbook depicts male scientists as inventors and includes a discussion of female scientists. Most of the textbooks convey the message that girls or women are passive, weak, and submissive.

On the other hand, men are powerful, assertive, intelligent, authoritative, and societal leaders. The science textbook analysis shows there are different gender stereotypes, such as boys carrying out experiments. History textbook analysis mentions only boys or men as heroes in liberation struggles, but the textbooks have not mentioned heroines. Most characters in the textbooks are men (UNESCO, 2004). In textbooks and teaching-learning materials, girls or women are mentioned less frequently than boys or men (UNESCO, 2009). In most textbooks, the pronoun' he' is often used in textbooks and literature. Thus, FAWE (2005) recommended that teachers review the textbook and teaching-learning materials and utilize gender-responsive textbooks. There are female scientist, electrician, pilots, doctors, lawyers, police, chef, entrepreneurs, and lawyers in reality. 
The stereotype used in the textbooks and teaching-learning materials may determine how boys and girls choose their subject and ultimately their careers (UNESCO, 2009; UNESCO, 2004). Textbooks can influence users through their content, language, visuals, design (FAWE, 2005). Gender biases found in textbooks might create hindrances for males and females to opt for roles and responsibilities in the future (Saleem \& Zubair, 2013). Thus, gender analysis of textbooks is one way to consider issues in education (MOET, 2010).

In the Bhutanese education system, textbooks are often the only learning resource students and teachers use, and they drive teaching, learning, and assessment practices. Therefore, textbooks are a powerful teaching-learning resource that can impact the teaching-learning process and learning outcomes. Given their significant potential as learning resources, especially in contexts where assessment is commonly very much focused on the rote memorization and reproduction of prefabricated discourse, textbooks can easily become vehicles for promoting biases, including gender biases. Such biases can be promoted explicitly or more subtly (MOET, 2010). The textbook contents, illustration, images, assessment tasks, and value judgments incline to be gender-biased. It may hinder gender equality in education. Rather, a gender-neutral textbook can contribute to the development of open-mindedness and gender-sensitive attitudes and approaches (MOET, 2010).

According to the Curriculum and Professional Support Division (CAPSD) under the Ministry of Education, gender mainstreaming efforts with a gender adviser is taking place within the curriculum reform initiated in 2004. These efforts take different forms: integrating a gender perspective while reviewing textbooks and other teaching materials, ensuring a gender-balanced representation among writers, and including gender-related activities in the teacher guide where relevant. One of the "outcome, outputs and activities" under the goal: Gender Equality in education and training achieved in the National Plan of Action in Gender 2008-2013 (GNHC, 2007) reads as Gender roles and stereotypes removed from classrooms, in curricula, and textbooks for all levels of education and training. However, the recent textbook analysis from a gender perspective revealed gender-biased content, illustrations, exercises, and composition of writers, editors, reviewers, and classroom materials on wall displays.

FAWE (2005) also suggests reviewing textbooks to portray positive images of both men and women. Several countries like Ghana, Namibia, and Zambia have undergone educational reforms to remove gender bias from their teaching-learning materials and produce textbooks that positively represent men and women and are responsive to new development. According to the United Nations (1995), girls and boys should be treated equally and be encouraged to achieve their full potential in the educational and social environment. The educational resources should promote non-stereotyped images of women and men to eliminate inequality between boys and girls. Similarly, UNESCO (2000) in the Dakar Framework for Action condemns gender stereotypes from education programs. Gender fair curricula are important to promote gender equality. In particular, it explores society's full potential, including both boys and girls in talents, creativity, and innovativeness ( $\mathrm{Hey}, 2010)$.

National Plan of Action on Gender 2008-2013 (GNHC, 2007) suggests activities identified to address this include conducting research; reviewing teaching materials and curricula content from a gender perspective; sensitizing and creating awareness on gender and prejudices and stereotypes among key stakeholders, and using the media to portray women and men positively.

Bhutan Council for School Examinations and Assessment (BCSEA, 2013), through its study of Student Achievements in English Literacy and Mathematics Literacy in class X, recommended the following to Curriculum Developers, Teacher Trainers, and schools:

1. Reduce the gender gap in Mathematics, programs, and manual could be reviewed to include more girl-friendly content, and mathematics teaching to girls be emphasized,

2. Include gender issues by modifying teachers' representation and persistent stereotype of girls being less talented in Mathematics.

3. Pay equal attention and provide equitable support to both girls and boys in their learning.

Therefore, the study attempted to study the curricular materials, mainly textbooks, which form the main resource for both teachers and students for the existence of any gender issues and gender biases in the contents, illustrations, and learning activities 


\section{The objective of the study}

Several studies on gender in textbooks have been carried over the world since 1970 (Saleem \& Zubair, 2013). No research has previously been carried out on textbooks in Bhutan. The study's main objectives were to identify gender bias and stereotypes in textbooks through analysis of textbooks and curriculum frameworks from a gender perspective.

\section{Significance of the study}

The study's findings will be useful for textbook developing agencies, policymakers, textbooks writers, teachers in developing a gender-sensitive curriculum, and textbooks.

\section{METHODS}

The researchers reviewed the following curriculum frameworks:

1. Accountancy, Provisional Edition, 2018;

2. Economics Curriculum Framework IX-XII, Provisional Edition, 2018;

3. English Curriculum Framework PP-XII, Provisional Edition 2005, 2006, Revised 2007 Reprint 2015;

4. Geography Curriculum Framework PP-XII, Provisional Edition 2018;

5. Mathematics Curriculum Framework PP-XII, Provisional Edition 2005;

6. Science Curriculum Framework PP-XII, Provisional Edition 2012.

Four workshops were organized in Paro, Trongsa, Punakha, and Trashigang to cover the country's western, central and eastern regions. Teachers teaching classes IX to XII were nominated by Schools through Dzongkhags/Thromdes to participate in the workshops. 22 female and 54 male teachers participated in the workshops. Participants were instructed to bring along the textbooks they used for teaching and their laptops. Once at the venue, participants formed subject groups with at least two teachers for every subject.

In most cases, there were at least two teachers (both male and female) analyzing a subject ranging from classes IX to XII because usually, it is the same teacher teaching the same subject in two or three levels of classes. Working in small groups helped teachers discuss the gender typing they discover in the textbooks and confirm their findings through verification. This way of textbook analysis helped collect first-hand information on gender sensitivity in the existing curriculum, particularly textbooks.

Blumberg's (2007, p.52-54) model of textbook analysis employed to analyze gender biases in Vietnamese primary school textbooks (MOET, 2010) was adapted to guide analysis of textbooks for classes IX to XII used in the Bhutanese schools. To support real communication, a presentation on the definitions and terminologies on gender and gender bias terms and gender-inclusive terms was made to the teachers so that the common "unspoken assumption that listeners and readers already know the meaning and therefore the explanation is unnecessary" (Glasser \& Smith III, 2008, p.343), is addressed to clarify the meaning assigned to gender and the related term sex.

Following this, the participants used the matrix for textbook review (Table 1) adapted from MOET (2010) in identifying gender insensitive content, phrases, language, pictures, examples, learning activities, and assessment tasks and illustrations in the subjects taught. The analysis results were shared with other participants through a presentation by respective groups to validate the results. The data collected were compiled subject-wise, compared, and contrasted for confirmation and common understanding. The data was then randomly checked with the respective textbooks for further confirmation.

Table 1. Matrix for Textbook Review

\begin{tabular}{|c|c|c|c|c|c|}
\hline \multicolumn{6}{|c|}{ 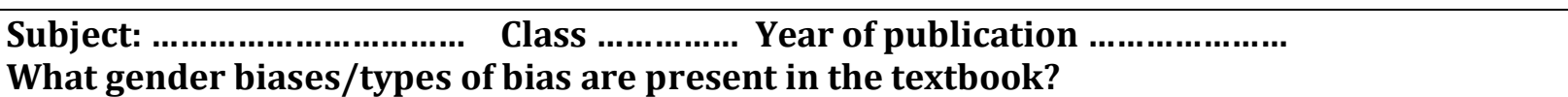 } \\
\hline $\begin{array}{l}\text { What } \\
\text { Bias? }\end{array}$ & $\begin{array}{l}\text { Textbook } \\
\text { author \& } \\
\text { Textbook } \\
\text { editors (How } \\
\text { many males } \\
\text { and females }\end{array}$ & $\begin{array}{l}\text { Content } \\
\text { (statement; } \\
\text { examples) (how } \\
\text { male and female } \\
\text { characters are } \\
\text { presented; is }\end{array}$ & $\begin{array}{l}\text { Illustrations } \\
\text { and Graphic } \\
\text { design (how } \\
\text { men and } \\
\text { women are } \\
\text { depicted/Are }\end{array}$ & $\begin{array}{l}\text { Student activities } \\
\text { (whether there is } \\
\text { a good balance in } \\
\text { supporting and } \\
\text { challenging both } \\
\text { boys and girls; }\end{array}$ & $\begin{array}{l}\text { Assessment } \\
\text { (whether both } \\
\text { boys and girls are } \\
\text { trusted to be able } \\
\text { to carry out } \\
\text { complex tasks }\end{array}$ \\
\hline
\end{tabular}




\begin{tabular}{|c|c|c|c|}
\hline \multicolumn{4}{|c|}{$\begin{array}{l}\text { Subject: ................................ Class ............... Year of publication } \\
\text { What gender biases/types of bias are present in the textbook? }\end{array}$} \\
\hline $\begin{array}{l}\text { reference made } \\
\text { to both male } \\
\text { and female }\end{array}$ & $\begin{array}{l}\text { there a } \\
\text { balance of } \\
\text { numbers and } \\
\text { quality of } \\
\text { engagement) }\end{array}$ & $\begin{array}{l}\text { whether both } \\
\text { genders are } \\
\text { trusted with } \\
\text { leadership and } \\
\text { organizational } \\
\text { capacities) }\end{array}$ & $\begin{array}{l}\text { instead of } \\
\text { suggesting that } \\
\text { they should be } \\
\text { challenged } \\
\text { differently based } \\
\text { on their gender } \\
\text { instead of } \\
\text { individuals) }\end{array}$ \\
\hline
\end{tabular}

Source: MOET (2010)

Table 2. Gender bias and gender-inclusive terms

\begin{tabular}{ll}
\hline Gender bias terms & Gender-inclusive terms \\
\hline Mankind & Human Kind \\
Man Power & Workforce/human resource \\
Police Man & Police Officer \\
Fireman & Fire Fighter \\
Chairman & Chairperson/Chair \\
Waiter & Server \\
Businessman & Business Executive \\
The Story of Man & The story of human \\
Man-Made & Human Made/ Human Construct \\
Mailman/Postman & Letter Carrier \\
Security Man & Security Officer \\
Steward/Stewardess & Flight Attendant \\
Brotherhood & Kinship \\
Craftsman & Craftsperson \\
Brotherly & Friendly \\
Spokes Man & Spokesperson \\
Workmanship & Craftsperson \\
He & S/he \\
Craftsman & Craftsperson \\
Miss/Mrs & Ms \\
Man-made & Human constructed \\
The story of a man & The story of human \\
\hline
\end{tabular}

Source: Srivastava (n.d)

\section{RESULTS AND DISCUSSION}

\section{Curriculum framework}

The framework for the development of a new curriculum or improving existing curriculum need to spell out the guiding principles of curriculum development such as the age and grade appropriateness, time, developmentally progressive, culturally appropriate, gender-sensitive, special needs, inclusive, national and global context, vocations, sustainability, lifelong learning educational goals, and curriculum standards, learning outcomes at key learning stages (REC, 2018, p.22). However, upon analysis, it was found that none of the other curriculum frameworks addressed gender except for the curriculum framework for science. The science curriculum framework attempted to address the gender aspect under its guiding principles. The guiding principle states that "It is important that the teachers ensure equal participation of boys and girls in all aspects of the science learning process, consistently use non-sexist language and avoid competitive approaches in curriculum design and teaching. Activities, materials, and resources must be developed by the curriculum designers that will appeal to both girls and boys, and be relevant to their lives" (REC, 2018, p. 7). 


\section{National School Curriculum Conference}

In 2016, the first-ever National School Curriculum Conference was carried out with the aims to reflect on the school curriculum to make it more relevant to the current national and global contexts to enable learners to be creative, communicative, critical thinkers, collaborative, innovative, and enterprising, and b) guide to design immediate, short, medium and long-term strategic plans for curriculum reforms ( $\mathrm{REC}, 2016$, p. 2). As of 2016, the date of the last revision of textbooks stood as shown in Table 3.

Table 3. Date of last revision of the textbook

\begin{tabular}{|c|c|c|c|}
\hline \multicolumn{2}{|c|}{ Subjects } & \multirow{2}{*}{$\begin{array}{l}\text { Class levels } \\
\text { PP to XII }\end{array}$} & \multirow{2}{*}{$\begin{array}{l}\text { Date of last revision of the textbook } \\
2010\end{array}$} \\
\hline 1 & Dzongkha & & \\
\hline 2 & English & PP to XII & 2010 \\
\hline 3 & Mathematics & PP to XII & 2008 (PP) / 2010 (VI) / 2011 (XII) \\
\hline 4 & Environmental Studies (EVS) & PP to III & 2004 (PP) / 2014 (III) \\
\hline 5 & Science (General) & IV to VIII & 2012 (IV) / 2014 (VIII) \\
\hline 6 & History and Civics & VII to XII & 2010 (VII) / 2005 (XII) \\
\hline 7 & Geography & VII to XII & 1998 (VII) / 2005 (XII) \\
\hline 8 & Environmental Science & IX to $X$ & 2015 \\
\hline 9 & Biology & IX to XII & 2014 (IX) / 2016 (XII) \\
\hline 10 & Chemistry & IX to XII & 2015 \\
\hline 11 & Physics & IX to XII & 2014 (IX) / 2016 (XII) \\
\hline 12 & Economics & IX to XII & 2014 (IX) / 2005 (XII) \\
\hline 13 & ICT & IX to XII & 2004 (IX) / 2003 (XII) \\
\hline 14 & Accountancy & XI and XII & 2003 (XI) / 2012 (XII) \\
\hline 15 & Agriculture and Food Safety & $\mathrm{XI}$ and XII & 2015 \\
\hline 16 & Commerce & $\mathrm{XI}$ and XII & 2004 (XI) / 2005 (XII) \\
\hline 17 & Media Studies & XI and XII & 2015 \\
\hline 18 & Rigzhung & XI and XII & 2012 \\
\hline
\end{tabular}

Source: REC (2016. p.12)

The 2016 National School Curriculum Conference report is generally silent on gender inclusion in the school curriculum. All subjects analyzed respective themes of the subject, outlined recommendations, and drew up an action plan. But gender sensitivity is absent in all the respective themes. However, health and physical education stated the need to include class PP to VI learners in health and physical education irrespective of age, gender, or different abilities (REC, 2016, p.28). It does not imply that health and physical education explicitly considered the gender dimension in the primary school curriculum. It showed that only gender in terms of including girls and differently-abled students are considered. In the revision, development, or selection of textbooks and teaching and learning materials by the REC, the text materials are assessed on the accuracy, currency, and alignment against the standards and learning outcomes relevant to the Bhutanese society and the global world. According to (REC 2018, p.23), identifying, revising, or developing teaching and learning resources shall be done following the holistic approach to education given in the framework such as textbooks, manuals, workbooks, readers, charts, equipment. When the curriculum frameworks for the various subjects miss out on covering gender matters, it is far from reality that the curricular material developed or selected will address gender matters. For example, although the curriculum framework for science has mentioned gender in the framework, it does not guarantee that gender will be addressed in the textbooks or the teaching-learning process.

Table 4. Textbooks reviewed with a gender perspective

\begin{tabular}{lll}
\hline Sl. No. & Class & Subjects \\
\hline $\mathbf{1}$ & XII & 1. Economics, \\
& & 2. Chemistry,
\end{tabular}




\begin{tabular}{|c|c|c|}
\hline Sl. No. & Class & Subjects \\
\hline 2 & XI & $\begin{array}{l}\text { 3. Commerce Reprinted } 2017 \text { (A complete course in ISC Commerce, Volume } \\
\text { II) } \\
\text { 4. English (Reading and Literature, The Merchant of Venice), } 2013 \\
\text { 1. Economics, } \\
\text { 2. English, Publication } 2014 \\
\text { 3. Geography, } \\
\text { 4. Accountancy, Publication } 2018 \\
\text { 5. Mathematics, } \\
\text { Rioloov Publication } 2018\end{array}$ \\
\hline 3 & $X$ & $\begin{array}{l}\text { 6. Biology, Publication } 2018 \\
\text { 1. Economics, Published } 2013 \\
\text { 2. English, Publication } 2010 \\
\text { 3. Chemistry, Publication } 2017 \\
\text { 4. Chemistry, Publication } 2016 \\
\text { 5. Mathematics, Publication } 2007 \text {, DCRD } \\
\text { 6. Physics Publication } 2015 \\
\text { 7. Biology, Publication } 2016 \\
\text { 8. Bhutan Geography, CAPSD 1994, reprint 2008, second edition } 2006\end{array}$ \\
\hline 4 & IX & $\begin{array}{l}\text { 1. Introductory Economics, Published } 2012 \\
\text { 2. English, Publication } 2017 \\
\text { 3. History, } \\
\text { 4. Chemistry, } 2017 \\
\text { 5. Bhutan Geography, CAPSD 1994, reprint 2008, second edition } 2006 \\
\text { 6. Bhutan Civics IX \& X Publication 2008; Reprint 2011; Reprint } 2017 \\
\text { 7. Physics, Publication } 2014 \\
\text { 8. Biology Publication } 2016\end{array}$ \\
\hline
\end{tabular}

\section{Textbook review}

Author, editor, and reviewer

There is an over-proportional number of males in the list of writers, reviewers, editors, advisors, designers, and facilitators. Learners need to notice that both men and women can be textbook authors, reviewers, editors, designers. The predominance of one gender (and the absence of the other) in the case of different subjects may trigger the belief that gender is associated with excellence in certain areas. Moreover, if only men are authors, reviewers, illustrators, and advisors, women's voices and experiences may be excluded (MOET, 2010).

\section{Content of the textbook}

Overall, there is a gender-segregated selection of content, illustrations and displays, and student learning activities. The content, diagrams and illustrations, and activities do not consider existing gender inequalities. For example, socio-cultural perceptions generally hold women as less confident, less capable, weak, and sexually more vulnerable than men and these are seen depicted in the textbooks. The change, although slow, is visible. Women and men are increasingly engaging in activities generally not considered typical of their sex, and women are especially coming forward to challenge culturally accepted stereotypes. The contents generally are gender-biased, discriminating, and do not portray women as having equal value as men.

Most contents had male protagonists, examples of cases dominated by male characters and stories, and examples had stereotypical portrayals of males in leading roles, owing businesses, decisionmaking, and dominant roles in Economics textbooks. Women and girls are portrayed as submissive and engaging in hard, laborious work where educational qualification and high-level analytical thinking were not required. Most contents used gender-biased terms such as man, policeman, chairman, learned men, businessmen, mankind, biodiversity and man, volcanoes and man in Geography, History and Civics textbooks. The names of companies used in the textbooks are male-oriented, including the examples used in student activities. Major contributions were acknowledged to males, be it humans or deities, in 
business managerial positions, such as board members. Social impacts of alcohol are shown to be impacting only females. Female-oriented quotations such as, "If a woman decides, it is the decision for the family," "Educating girls means educating future mothers" are also seen in the Bhutan Geography textbooks.

In subjects such as Mathematics, textbook content showed efforts to make the textbook genderneutral by using gender-neutral names in examples and questions. Most articles, stories, and poems in English depict women as fragile, weak, tender, soft-hearted, and the male is strong, enduring, industrious, and determined.

Table 5. Sample of a textbook analysis

\section{Subject: Mathematics Class: $\mathrm{X}$}

What gender biases/types of bias are present in the textbook

\begin{tabular}{|c|c|c|c|c|c|}
\hline What bias? & $\begin{array}{l}\text { Textbook } \\
\text { authors \& } \\
\text { Textbook } \\
\text { editors }\end{array}$ & $\begin{array}{l}\text { Content } \\
\text { (statements; } \\
\text { examples) }\end{array}$ & $\begin{array}{l}\text { Illustrations \& } \\
\text { Graphic design }\end{array}$ & $\begin{array}{l}\text { Student } \\
\text { activities }\end{array}$ & Assessment \\
\hline Stereotyping & $\begin{array}{l}\text { Advisors: } 4 \\
\text { male } \\
\text { Author: } 4 \\
\text { males, one } \\
\text { female } \\
\text { Bhutanese } \\
\text { reviewers: } 19 \\
\text { males, two } \\
\text { female } \\
\text { Cover concept } \\
\text { and design: } 2 \\
\text { male } \\
\text { Coordination: } \\
2 \text { male } \\
\text { Editor: } 1 \\
\text { male, one } \\
\text { female }\end{array}$ & $\begin{array}{l}\text { Examples of } \\
\text { questions are } \\
\text { refereed } \\
\text { equally to } \\
\text { both males } \\
\text { and females. }\end{array}$ & $\begin{array}{l}\text { A question related } \\
\text { to drawing digraphs } \\
\text { is based on a } \\
\text { tournament held, } \\
\text { where the picture } \\
\text { depicts only male } \\
\text { students playing } \\
\text { volleyball (page no: } \\
\text { 29). } \\
\text { Pictures depicting } \\
\text { men running and } \\
\text { riding bicycles in a } \\
\text { tournament (pg no: } \\
\text { 92). } \\
\text { A man was } \\
\text { throwing a discus } \\
\text { depicting the } \\
\text { involvement of men } \\
\text { in sports (pg no: } \\
\text { 199). } \\
\text { The extract on page } \\
279 \text { illustrates that } \\
\text { women's bodies are } \\
\text { designed to give } \\
\text { birth, whereas the } \\
\text { picture illustrated a } \\
\text { woman carrying a } \\
\text { child on her } \\
\text { shoulder. This } \\
\text { image might in-still } \\
\text { the notion that it is } \\
\text { a woman's } \\
\text { responsibility to }\end{array}$ & $\begin{array}{l}\text { Some of the } \\
\text { questions } \\
\text { reflected in } \\
\text { the text } \\
\text { illustrate the } \\
\text { imbalance of } \\
\text { the intensity } \\
\text { of the work } \\
\text { done by men } \\
\text { and women. } \\
\text { For instance, } \\
\text { females are } \\
\text { usually } \\
\text { described in } \\
\text { a situation } \\
\text { that requires } \\
\text { less labor } \\
\text { work (pg no: } \\
\text { 126, question } \\
\text { number 4) } \\
\text { and 9pg no: } \\
\text { 134, question } \\
\text { number } 8 \text { ). } \\
\text { Furthermore, } \\
\text { males are } \\
\text { described in } \\
\text { a situation } \\
\text { that demands } \\
\text { more labor } \\
\text { work (pg no: } \\
\text { 133, example } \\
\text { question 2), } \\
\text { (page } \\
\text { number: 120, } \\
\text { question }\end{array}$ & \\
\hline
\end{tabular}




\begin{tabular}{llllll}
\hline What bias? & $\begin{array}{c}\text { Textbook } \\
\text { authors \& } \\
\text { Textbook } \\
\text { editors }\end{array}$ & $\begin{array}{l}\text { Content } \\
\text { (statements; } \\
\text { examples) }\end{array}$ & $\begin{array}{l}\text { Illustrations \& } \\
\text { Graphic design }\end{array}$ & $\begin{array}{l}\text { Student } \\
\text { activities }\end{array}$ & Assessment \\
\hline & & $\begin{array}{l}\text { take care of } \\
\text { children. }\end{array}$ & $\begin{array}{l}\text { number 5 } \\
\text { and 6). }\end{array}$ & \\
\hline
\end{tabular}

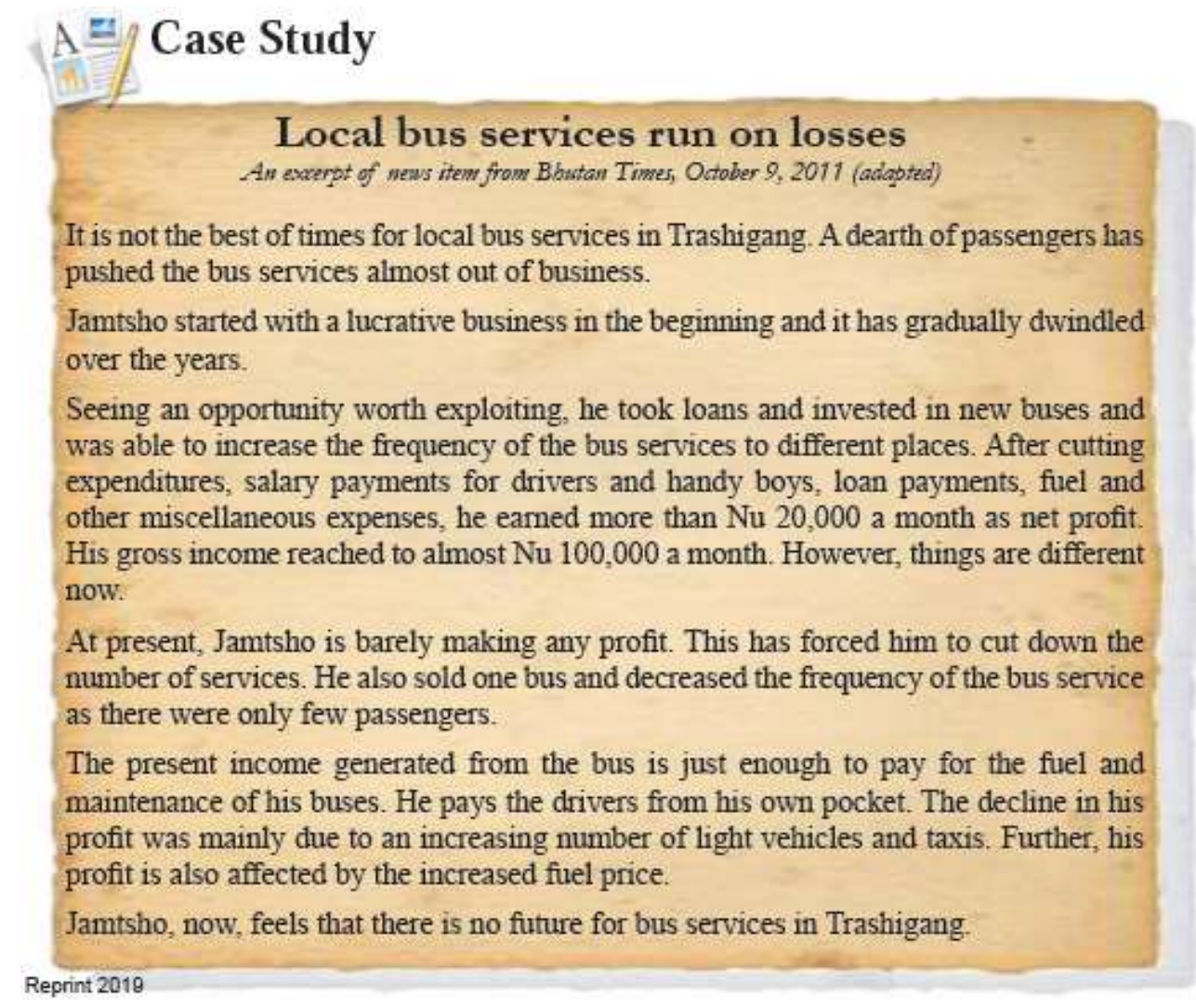

Source: Introductory Economics, A Course Book for Class X (REC, 2019, p.31)

Figure 1. Case study 1

\section{Illustrations and graphic design}

It refers to how men and women are depicted in the textbooks; whether there is always a quantitative and qualitative balance of representations of men and women; whether graphic elements avoid positioning different characters in a marginalized and inferior situation; whether illustrations or graphic design are offensive to men or women (MOET, 2010). Most diagrammatic representations were only males; there was a balance of males and females represented in a few cases. There are images of male thinkers only in Economics textbooks; while initially there would have been only males pursuing academics, the role of women in modern development could have found someplace in the textbooks.

Women were illustrated as teachers, nurses, customers, engaged in husking, harvesting, plantation, while men are depicted as police personnel, fishing, farming, medical staff, telephone operators, business owners, and machinery operators in Economics. Illustrations also showed males running, playing volleyball, throwing the discus. In Physics textbooks, examples of force, work, power, energy, and required labor are mostly male characters. Girls and women are depicted as cooking, sweeping, onlookers, while males stereotype women's roles as wives, mothers, and caregivers. 


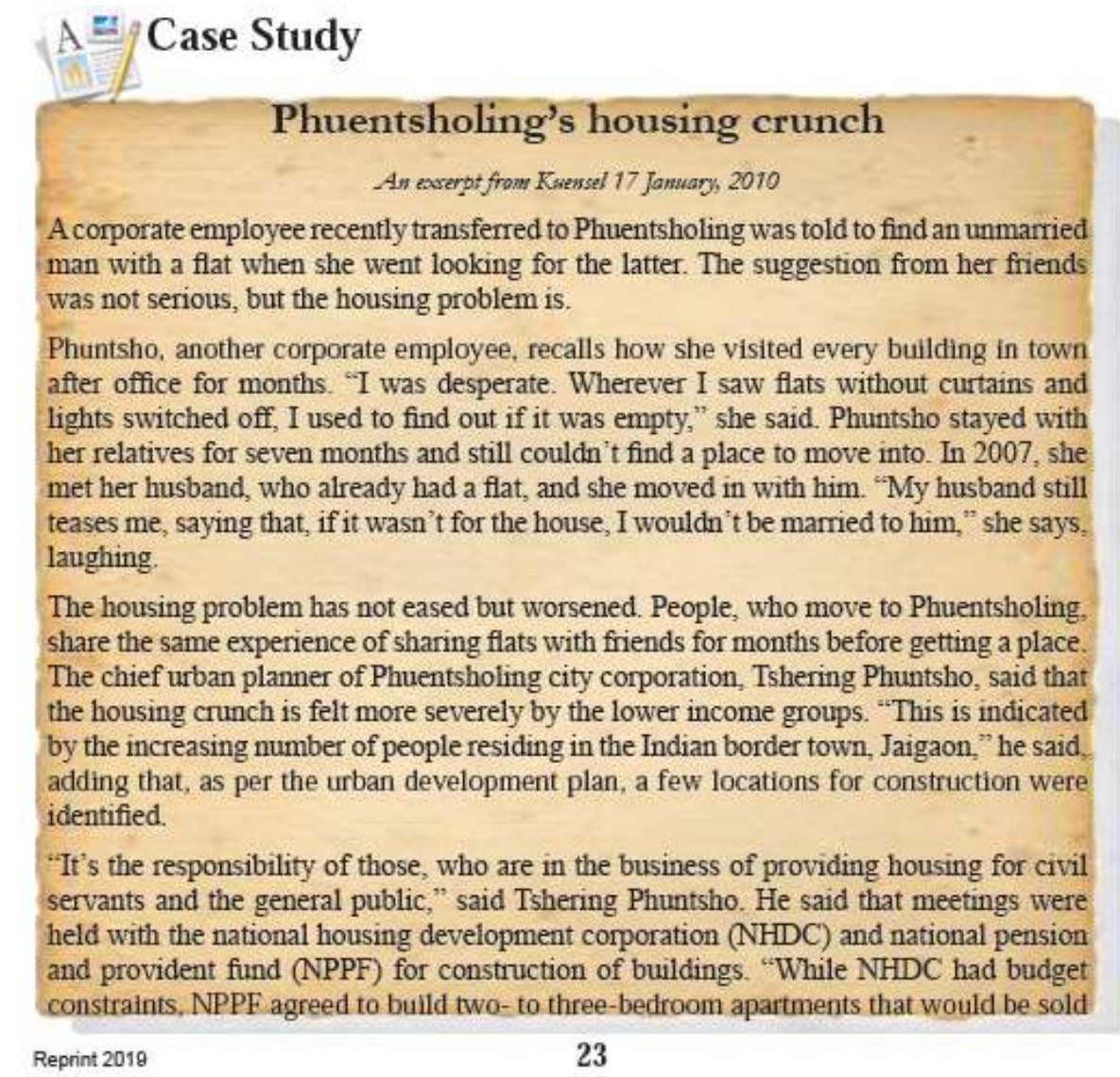

Source: Introductory Economics: A Course Book for Class X (REC, 2019, P.23)

Figure 2. Case study 2

\section{Learning Activities}

Some textbooks had gender-neutral student learning activities, but most had males leading businesses, showing males as risk-takers and business starters. Many activities were male-oriented. Learning activities illustrated typical stereotyping by situating females in less labor-intensive and males in more labor-intensive works.

Used of the pronoun "he" "his" was rampant. Questions depicting physical involvement and questions requiring critical thinking are male-oriented while low order thinking questions were femaleoriented in Mathematics textbooks; similarly, male characters were presented for framing the question related to sports and bike race, driving, and physical activities while the female character was used in framing question related to household chores in Physics textbooks. In depicting students doing experiments, mostly male characters are seen engaged in experiments.

\section{Assessment}

The assessment usually involved students with the same assessment questions. In some cases, rubrics were used for the assessment of student works. No gender biases or discrimination were evident from the textbooks. In a study on assessing girls' participation in education at higher secondary level in Bhutan, Samdrup (2009) reports that, of the teachers interviewed $(\mathrm{N}=146)$, the majority (85 percent) agree that the curriculum as of 2009 is girl-friendly. Of the 85 percent, it was explained that the curriculum was gender-neutral (38 percent) and free from gender bias (48 percent). However, some (15 percent) reported that the curriculum in 2009 was not girl-friendly, and it continued to be genderbiased in the portrayal of women. The result indicates that the current curriculum is not as girl-friendly as it should be. It seems that the current textbooks still have gender-biased content, although effort seems to be made by the curriculum developers. In an earlier study on Gender Responsive Pedagogy Awareness and Practices by Dorji (2020), the findings revealed that teachers do not know much about 
gender and gender-responsive pedagogy. The findings supported the results of Saleem \& Zubair (2013), who carried a similar study on under-representing women in curricula: a content analysis of Urdu and English textbooks at the primary level in Pakistan.

\section{CONCLUSION}

Based on the evidence, the study concluded that the curriculum is not gender-sensitive, and biases towards females were prevalent. Despite a set of guidelines to eliminate gender stereotypes in textbooks, not much has been done so far. More improvement in the curriculum is needed to eliminate gender biases in education successfully. The study also found the imbalance of gender in the list of authors, reviewers, editors, and designers and the presence of gender biases, genderstereotypical content, and illustrations in the textbooks. Similarly, female characters and female portrayals do not reflect the true role of women.

Since textbooks are the main resource and that it has the potential to transmit gender stereotypes, curriculum developers must make use of dedicated organizations expertise in developing curriculum content; optimize the composition of working groups that develop curricula to include perspectives of both males and females; integrate principles of gender sensitivity in developing curricular materials, particularly textbooks; use a gender screening tool to ensure materials in text and visuals are gender-sensitive; and strongly consider gender aspects in the contents. Promote greater gender-friendly curriculum development and implementation through continuous discourse and professional development for teachers on integrating gender and addressing gender in their practice. Teachers can encourage and counsel students, especially female students, to break the stereotypes.

\section{Limitation \& Implication of the study}

It was impossible to have an equal number of male and female respondents since it was impossible for the researcher to dictate participants. For the textbooks analysis, participants were from among the teachers teaching middle and higher secondary levels where the pool of female teachers is smaller than that of male teachers. Since gender in education is a complex subject and this study focuses mainly on the textbook analysis of secondary education, further research and investigation in other areas of concern relating to gender in education are called for. Future research in the same field is recommended to employ a mixed-method approach, including surveys with students, teachers, policymakers; focus group discussions with parents, teachers, and students; and interviews with policymakers and school leaders on textbooks.

\section{The researchers would like to thank the:}

1. UNESCO Participation Programme 2018-2019 for the financial assistance without which this study would not have been possible;

2. Royal Education Council for rendering administrative support;

3. Dzongkhag and Thromde Education Offices, principals, teachers, students, and participating schools for their cooperation and necessary support. We extend our gratitude to those whose names would have been missed from the list. Any shortcoming in the study is sole of the researchers.

\section{Conflicts of Interest:}

The authors declare that there are no conflicts of interest for this article.

\section{REFERENCES}

Aksornkool, N. (1997). Gender-Sensitive Education for a Better World. Background Document. Paris, France: UNESCO.

BCSEA. (2013). A Study of Student Achievement in English Literacy and Mathematics Literacy in Class X. National Education Assessment Technical Report 2013-2014. Thimphu, Bhutan: BCSEA.

BCSEA. (2019). Education in Bhutan: Findings from Bhutan's experience in PISA for Development. 
Thimphu, Bhutan: National Project Centre, Bhutan Council for School Examinations and Assessment.

BCSEA. (2019). Launch of Bhutan PISA-D National Report. Thimphu, Bhutan: BCSEA.

BCSEA. (2014). Pupil Performance Report 2014, 2017. Thimphu, Bhutan: BCSEA.

Buchmann, C., DiPrete, T. A., \& MCDaniel, A. (2008). Gender Inequalities in Education. Annual Review of Sociology, 34, 319-337. DOI: https://10.1146/annurev.soc.34.040507.134719

Blumberg, R.L. (2007). Gender bias in textbooks: A hidden obstacle on the road to gender equality in education. Vietnam: UNESCO Ha Noi Office.

CAPSD. (2005). Mathematics Curriculum Framework for Classes PP-XII. Paro, Bhutan: CAPSD.

DCRD. (2005). English Curriculum Framework Class PP-XII. Paro, Bhutan: DCRD.

Dorji, T. (2020). Gender Responsive Pedagogy Awareness and Practices: A Case Study of a Higher Secondary School under Thimphu Thromde, Bhutan. International Journal of Linguistics and Translation Studies, 1(2), 100-111.

Dorji, T. (2017). Gender Gap in the Constituent Colleges of the Royal University of Bhutan- Reasons and Implications for Gender Equality. RABSEL the CERD Educational Journal, 18(2), 61-82.

FAWE. (2005). Gender Responsive Pedagogy: A Teacher's Handbook. Nairobi, Kenya: FAWE.

Glasser, H.M., \& Smith III, JP (2008). On the Vague Meaning of "Gender" in Education Research: The Problem, Its Sources, and Recommendations for Practice. Educational Researcher, 37 (6), 343350.

GNHC. (2019). Twelfth Five Year Plan 2018-2023: Just, Harmonious and Sustainable Society through Enhanced Decentralization. Thimphu, Bhutan: GNHC.

GNHC. (2007). National Plan of Action for Gender 2008-2013. Thimphu, Bhutan: GNHC.

Hey, B. (2010). Guidelines on Gender Fair Curriculum Development. Graz, Austria: WUS Austria.

MoE. (2014). Bhutan Education Blueprint 2014 - 2024: Rethinking Education. Thimphu, Bhutan: MoE.

MoE. (2014). Annual education statistics 2014. Thimphu, Bhutan: MoE.

MoE. (2019). Annual education statistics 2019. Thimphu, Bhutan: MoE.

MOET. (2010). Guidelines for textbook review and analysis from a gender perspective. Vietnam: UNESCO Ha Noi Office.

National Statistics Bureau of Bhutan. (2012). Bhutan Living Standards Survey 2012 Report. Thimphu, Bhutan: National Statistics Bureau of Bhutan.

NSB. (2017). Population and Housing Census of Bhutan 2017. Thimphu, Bhutan: NSB.

Pigozzj, M.Y. (2000). Girls' Education: Improving both Access and Quality. France: UNICEF.

Reeves, H., \& Baden, S. (2000). Gender and Development: Concepts and Definitions Prepared for the Department for International Development (DFID) for its gender mainstreaming intranet resource. Brighton, UK: Institute of Development Studies (University of Sussex).

REC. (2012). Science Curriculum Framework PP-XII. Paro, Bhutan: REC.

REC. (2016). National School Curriculum Conference 2016: Rethinking Curriculum Report. Paro, Bhutan: REC.

REC. (2018). Royal Education Council Operational Framework. Paro, Bhutan: REC.

REC. (2018). Accountancy Curriculum Framework. Paro, Bhutan: REC.

REC. (2018). Economics Curriculum Framework IX-XII. Paro, Bhutan: REC. 
REC. (2018). Geography Curriculum Framework Class PP-XII. Paro, Bhutan: REC.

REC. (2019). Introductory Economics: A Couse Book for Class X. Paro, Bhutan: REC.

Rinzin, Y.C. (2019, April 1). Students learning without understanding. Kuensel. Retrieved from http://www.kuenselonline.com/students-learning-without-understanding/

Saleem, F., \& Zubair, S. (2013). (Under) Representing women in Curricula: a content analysis of Urdu and English Textbooks at the primary level in Pakistan. Pakistan Journal of Women's Studies, 20(1), 57-71.

Samdrup, R. (2009). Glass ceiling in the educational curve for girls: Assessing girls' participation in education at higher secondary level in Bhutan. Thimphu, Bhutan: MoE.

Sonam, P. (2019, April 17). Top performing schools in 2018. BBS. Retrieved from http://www.bbs.bt/news/?p=113042

Srivastava, G. (n.d). Gender Concerns in Education. New Delhi, India: NCERT.

United Nations. (1995). Beijing Declaration and Platform for Action. Report of the Fourth World Conference in Women in Beijing, China.

UNESCO. (2015). A Guide for Gender Equality in Teacher Education Policy and Practices. Retrieved from http://www.unesco.org/education/tlsh/

UNDP. (2003). Human Development Report 2003: Millennium Development Goals: A Compact among nations to end human poverty. New York, USA: UNDP.

UNDP. (2016). Human Development Report 2016: Human Development for Everyone. New York, USA: UNDP.

UNESCO. (2000). World Education Forum-Framework for Action. Dakar, Senegal: UNESCO.

UNESCO. (2004). Gender Sensitivity: A training manual for sensitizing education managers, curriculum and material developers, and media professionals to gender concerns. France: UNESCO.

UNESCO. (2005). Exploring and Understanding Gender in Education: A Qualitative Research Manual for Education Practitioners and Gender Focal Points. Bangkok, Thailand: UNESCO.

UNESCO. (2009). Gender in Education Network in Asia-Pacific (GENIA) Toolkit: Promoting Gender Equality in Education. Bangkok, Thailand: UNESCO.

UNESCO. (2014). Teaching and Learning: Achieving quality for all. France: UNESCO.

UNICEF. (2017). Annual Report 2017 Gender Equality and Rights. Kathmandu, Nepal: UNICEF.

World Bank. (2011). Gender equality and development. Retrieved from https://openknowledge.worldbank.org/handle/10986/4391

World Bank. (2012). World Development Report 2012: Gender Equality and Development. Washington DC, USA: World Bank. 